\title{
Local Action to End 1rafficking in Women in Nepal
}

An interview with Shanti Adhikari conducted by Stefanie Gude

Born in Nepal in 1961, Mrs. Shant Adhikari has completed her B.A. in Economics and a graduate degree in Women's Studies a Kathmandu's Tribhuvan Uni

versity. Currently, she acts as president of

CWISH, Children and Women in Social Service and Human Rights, in addition to co-ordinating the Women's Section of the NGO Federation of Nepal. Mrs. Adhikari also represents her organization as an active member of AA TWIN (the Alliance Against Trafficking in Women and Girls in Nepal).

Refuge asked Stefanie Gude, who recently returned to Canada from working in Kathmandu, Nepal, to interview Mrs. Adhikari, to provide important insight into the current state of trafficking in Nepal.

Stefanie Gude for Refuge: How would you describe the work of your organization? ShantiAdhikari:CWISH strives to empowe and improve the conditions of children and women who, due to forces of poverty, ignorance, and exploitation, are deprived of economic opportunities and social status-indeed, of their human rights. As well as working to stamp out trafficking, CWISH is teaching young children, many of whom work in tea shops and at other menial jobs, to read and write the Nepali language and script. This is for the purpose of enabling them to provide their families with assistance, by earning money outside of the home. CWISH has also been provided with a teacher and looms, to teach girls to weave. It is common practice for Kathmandu households to search the villages for young girls to work without wages in city homes. These girls are often badly housed, given few clothes and no opportunity for education. CWISH is training and educating such girls, as

\footnotetext{
Stefanie Gude has completed an honours degree in literature at McGill University and recently returned from living and working in Kilthmandu, Nepal.
}

well as looking to open a hostel to make it possible for them to leave such homes. Refuge: How does AA TWIN approach the struggle to end trafficking? What is its role as a lobby group in relation to SAARC (the South Asian Association for Regional Co-operation)?

Shan ti Adhikari: AATWIN is a network of 17 organizations fighting agains trafficking. It has carried out many advocacy, protest, and training programs. On the last Friday of each month, members of AA TWIN wear black dresses or saris as one form of protest. Thousands of pamphlets have also been distributed, in a massive effort to educate the public about trafficking. AAWTIN hopes to continue harnessing the energies of committed people and organizations dedicated to solving the problem of trafficking.

AA TWIN is currently co-ordinating a concerted effort to inform the public in those regions where trafficking takes place. The communities in such region are visited frequently, and women and girls receive information about methods of operation used by the traffickers, in the hopes of preventing contact altogether. Returnees from Indian brothels are questioned about their recruitment, and efforts are made to arrest and punish their abductors.
A campaign has been instituted throughout Nepal, orchestrating the sending of 200,000 letters to each SAARC head of state. The letters express the views of concerned Nepalese people about the trafficking of Nepalese citizens, and the lack of action by SAARC countries to prevent its occurrence. In 1996, a SAARC conference held in the Maldives addressed the subject, but none of the activities upon which that conference agreed have since been implemented. AA TWIN presented its concerns again in June of this year, prompting an agreement by leaders to abolish trafficking in the region. The letter campaign has succeeded in drawing the attention of all SAARC heads of state to this major issue.

Refuge: Which socio-economic factors do you believe contribute to the trafficking of women and children in Nepal?

ShantiAdhikari: A lack of education on the part of villagers, lack of employment opportunities, and the lack of social status held by women and children. Many families are conscious of the decision to send their girls to Bombay, stepmothers and uncles often playing a significant role in sending the girls away. Some girls are lured by the chance to receive money. While few actually make money, many are beaten and abused.

\section{CWIN \\ (Child Workers in Nepal Concerned Centre)}

Contact:8abIBhawan,. P.O.80x 4374, Kathmandu, Nepal

Fax: (009771) 278016 Emall: cwln@mos.com.np·cwln@volce.mos.com.np

Established In 1987, CWIN works to protect the rights of the child and to end .xpl9itatlVe cbi.ld Ittl:>9Urll1 N.pal. Tbefl'lainttrea.of cOl'lcerl'llnclude child lab9ur, prostitutiol'l,ll'Idmarr.lage, th.traffickh1g of children, and children on the streets. Besides lobbying governments, and promoting public awareness and Increased social consciousness, CWIN works directly with children, running programmesfor the .r8tae"'. am:t. ret\}..bIJltatiolJ of.cbllcir.n a, rlslt." has IfI'IPlement $\sim$ st ............t. ...11d comtnunltY-heaedactlohs to provide Shelter, foOd, health care, educauon, and skills training for such children. 
In Kathmandu alooe, there are over 200 brothela, crowded with minors. About 5,000 children under 16 years of age are Involved In the sex buai. nesaln,Nepal. As far as the traffick. Ing la concerned, the number of Nepalese girls forced into sex slav. ery in Indian arly 200,000 Every year about 5,000 to 7,000 chU ren are trafficked to Indian citie to be forced to work as prostitutes.

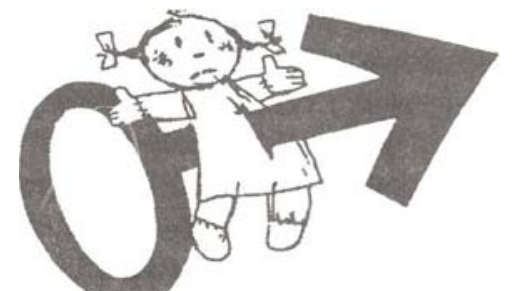

"She is called a prostitute. But that's not her name."

Large numbers of uneducated rural girls in Nepal are migrating to bigger cities In order to seek employment. Lured Into urban areas I?ythe prom. ise of prosperity, a goOd job and a bright future, lots of them end up Inthe street were they easily fall Into the sex industry. Some girls end up In carpet and garment factories, some. times used as conduit points for traf. flcklng girls to India. The girls are traf. flcklng girls to India. The girls are
also themselves prone to drift into com. merclal sex as.a means of surviving.

Reprinted wlthpermill_lon of CWiN.

For the most part, lower caste an casteless people are targeted, as they lack the close protection existing within higher caste families. There are some areas of Nepal in which prostitution is a woman's only means of earning money, and even the community accepts this.

Refuge: When and if trafficked women are returned to Nepal, what is life like for them? Is there any assistance available? ShantiAdhikari: There are four organisations who travel to India and bring back the girls-Maiti Nepal, ABC, WOREC (The Women's Rehabilitation Centre),andCEWIN (Child Workers in Nepal). When the girls return, they are housed together and provided with medical assistance, training, and rehabilitation. Ifpossible, they return to their own homes and families. These girls would otherwise be left homeless, as the community does not normally accept them again. They are given skills training, such as weaving, sewing, woodcarving, and bamboo crafting. Some are able to attend literacy programs and awareness classes. Some have actually attained quite high levels of education prior to being taken and can return to high school to continue their studies. Those with individual talents are encouraged to pursue them.

Refuge: What kind of action do the region's leaders propose to take?

ShantiAdhikari:The Foreign Ministers in attendance at the latestSAARC summit have met again since then. At the SAARC summit to be held in Nepal next year, the host country plans to have all leaders sign a convention abolishing the trafficking of women and girls. AA TWIN believes this convention will be signed, but may not be implemented by each country. AA TWIN will be working to lobby and pressure governments, as well as individua parliamentarians. Refuge: What are the consequences of trafficking in terms of $\mathrm{HI}$ V / AIDS?

Shanti Adhikari: The majority of girls tested are HIV positive. Very few have developed full-blown AIDS as yet, but hospices or hospitals will be a need in the future.

Refuge: What is most important to CWISH? to AA TWIN?

Shanti Adhikari: The top priority of CWISH is to stop all girl trafficking, and to empower women and girls, to close the gap between the status of men and women in Nepalese society.

AA TWIN's top priority is to abolish girl trafficking in Nepal by working closely with the SAARC countries, which have an effect on Nepal.

Refuge: What are the largest obstacles you face in trying to meet your goals?

Shanti Adhikari: With regards to trafficking,the main obstacle is Nepal's open border with India. We have 17 border crossings. Also, there are no stric punishments given to people involved in trafficking. There are minor laws in place, but AA TWIN is lobbying for stronger penalties.

Nepal's poverty is also an obstacle. Some of these girls actually return to India as they consider their chances of rehabilitation to be hopeless, and they prefer life in the brothel.

About 200,000 Nepali women and girls have been taken to India in the las t 20 years. Twenty percent have been less than 16 years old.

Interviewer's note: Pratima Khadka, President of the Bhutan Women and Children Organization, in exile in Kathmandu, has expressed great concern regarding the tenuous situation of young Bhutanese women living in Nepal. Crowded by the hundreds into refugee camps, these girls lack adequate income and job opportunities. Demanding immediate repatriation of the thousands of Bhutanese forced into exile on the basis of their ethnicity, Mrs. Khadka points out that it is their vulnerability, living the precarious existence of refugees, that makes these girls likely targets for traffickers. II

\section{Good Tourism ...}

"Respects the culture of the host nation "Operates In harmony with the environment

"Defends the rights of children "Gives equal respect and recognition to all people,

regardless of gender, race, physical

handicap, religion or age "Portrays and promotes Itself In a way which does not demean persons nor places "Ensures that the economic benefits of its activity TeaCh to all sectors of society

"Promotes positive values of peace and

Justice, harmony and understanding between peoples

Reprinted with permission of CWIN 